\title{
Escaping to Girlhood in Late Ottoman Istanbul: Demetra Vaka's and Selma Ekrem's Childhood Memories
}

\author{
Duygu Köksal
}

To the extent that childhood stays with us through reminiscences, traces of memory and impressions, writing one's childhood and recollections of growing up is an act of self-reflection and self-understanding. In many autobiographies, the part devoted to childhood is quite brief: narrating one's childhood in detail is a difficult exercise in memory, and it may be felt that the subject is of lesser interest to readers than later life. However, although an autobiographical work is a combination of fact and fiction, personal accounts of growing up are important sources for historical research; firstly, because they provide clues to the psychological make-up, family background and socialization of the person studied; and secondly, because they shed light on the whole process of the narrative reconstruction of early life, closing the distance between the present and the past. This chapter uses Demetra Vaka's A Child of the Orient (1914) and Selma Ekrem's Unveiled (1930) to explore different experiences of Ottoman childhood in nineteenth-century and early twentieth-century Istanbul, and how these were presented to foreign audiences. Both authors' coming-of-age narratives were written in English for Anglo-American audiences. ${ }^{1}$ I also refer to Demetra Vaka's earlier book, Haremlik, ${ }^{2}$ and her novella Bribed to be Born. This is a story about an Istanbulite Greek girl, and was greatly inspired by her own familial relations and upbringing. Her husband reported finding this among her papers after her death, and it was published posthumously in $195{ }^{1 .}{ }^{3}$

Demetra Vaka (1887-1946) was a novelist, a journalist and travel writer, and her writings include Orientalist works on the Muslim women of the Ottoman

1 Demetra Vaka, A Child of the Orient (London: John Lane, The Bodley Head, 1914); Selma Ekrem, Unveiled: Autobiography of a Turkish Girl (New York: Ives Wahburn, 1930). A facsimile reprint of Selma Ekrem's book, with a new introduction by Carolyn Goffman, was published in 2005: id. (Piscataway, NJ: Gorgias Press, 2005).

2 Demetra Vaka Brown, Haremlik: Some Pages from the Life of Turkish Women (New York: Houghton Mifflin, 1909). A facsimile, with a new introduction by Yiorgos D. Kalogeras, was published in 2005: id. (Piscataway, NJ: Gorgias Press, 2005).

3 Demetra Vaka (Mrs Kenneth Brown), Bribed to be Born (New York: Exposition Press, 1951).

(C) DUYGU KÖKSAL, 2016 | DOI 10.1163/9789004305809_012

This is an open access title distributed under the terms of the Creative Commons Attribution-

Noncommercial 3.0 Unported (CC-BY-NC 3.0) License. 
Empire. She also wrote more broadly on the late Ottoman Empire and its politics, the Eastern Question and the politics of the Great Powers, as well as Greek nationalism. Her ideological formation is a mixture of Greek nationalist ideas that she received from family members, a soft Ottomanism that she inherited largely due to her father's bureaucratic post in the Ottoman administration and a critique of modernity that she developed in her later life, especially while living in the United States.

Selma Ekrem (1902-1986) settled in the United States as a young woman, and she worked in Turkey's diplomatic missions in New York and in Washington. She was a lecturer and a journalist writing on the birth of modern Turkey until 1970s. Along with Unveiled, she was also the author of two books for youngsters: Turkey, Old and New (1947) and Turkish Fairy Tales (1964). ${ }^{4}$ She was the daughter of an upper-class, westernized bureaucratic family that witnessed the transition from the Empire to the Turkish Republic. Her ideological background combines an Ottomanism (Ottoman patriotism) mostly inherited from her family's bureaucratic and military position, a modernizing and liberal attitude critical of the Hamidian absolutist regime and later Turkish nationalism.

The Greek girl Demetra Vaka and the Turkish girl Selma Ekrem belonged to different communities of the Ottoman Empire and their writings demonstrate that their experiences of the age of dissolution of the Empire, nationalism and war were shaped by the particular circumstances of their communities. However, as children of Ottoman bureaucrats and modernized upper-class families, they shared an ideological environment; indeed, I argue here that they were raised according to quite similar childhood models. Although Vaka was about fifteen years older than Ekrem, they both grew up at a time of socioeconomic, material and ideological change: this was a period not only of changing clothes, homes, furniture and consumption patterns, but also a time when Westernization, Enlightenment values, constitutionalism and nationalism were very much in the air. Both their accounts of childhood are retrospective examinations of the nationalist strife, imperialist projects, modernization currents and social transformation experienced in the last decades of Ottoman Empire. This chapter will compare and contrast the two girls' development from childhood into girlhood, which in both cases led to their migration to the USA. I argue that both girls sought to escape the social conventions and moral obligations of their respective communities and deliberately opted for a childhood which extended into girlhood, compared to peers in their respective communities. In both cases, a prolonged girlhood was their response to familial and

4 Selma Ekrem, Turkey, Old and New (New York: C. Scribner's Sons, 1947); ead. Turkish Fairy Tales (Princeton, NJ: Van Nostrand, 1964). 
social pressures pushing them directly into womanhood. Both girls' escape to the USA - the land of freedom - should be understood in light of these attempts to prolong their girlhood. ${ }^{5}$

Vaka's late nineteenth-century childhood narrative is focused on the changes taking place within the modernizing Greek community of the Empire, and her encounters with an Oriental (i.e. Muslim) childhood. Her childhood narrative is organized around her feelings of difference, superiority and revulsion vis-à-vis Muslim children, although with simultaneous feelings of sympathy, pleasure and appreciation of her Muslim friends. Her writings are perfect examples of the larger body of Orientalist literature, since Vaka's account of Muslim children represents an unchanging reality, as if they were never touched by modernity, while Greek children were changing through modernization. In fact, Vaka seems to wish that the Muslim Orient she depicts to western audiences would never change. Ironically, she named her autobiographical work A Child of the Orient, putting herself in the shoes of an Orientalist writer who was herself almost an Oriental, but not quite.

Ekrem's early twentieth-century childhood, on the other hand, delineated by ideological change, political strife and war meant harsher conditions for Istanbul's children of all communities. By then, Vaka was already a young woman getting established as a writer and journalist in the USA. Ekrem, like Vaka, was born to a Westernized upper-class family. Her paternal grandfather was Namık Kemal, a famous Young Ottoman figure, whose liberal ideas had inspired generations of Ottomans; ${ }^{6}$ his son, her father, was Ali Ekrem, an important literary figure of the Servet-i Fünun, who first served as a secretary of Hamidian court and later, like Namı Kemal, as a governor in several Mediterranean provinces and islands of the Ottoman Empire. ${ }^{7}$

In Ekrem's childhood narrative, her central sentiment is the deep anxiety and insecurity experienced by her family under the Hamidian regime and later under conditions of ethnic strife and war (the Balkan Wars and the First World War). However, despite the tumultuous external conditions, the narratives demonstrate that Ekrem's earliest childhood was overall more protected and 'childlike' than

5 It was Elif Ekin Akşit who drew attention to the gradual rise of the idea of Muslim and Turkish girlhood in late Ottoman society. See her Kızların Sessizliği, Kız Enstitülerin Uzun Tarihi (İstanbul: İletişim, 2005), especially ${ }_{132-139}$.

6 For a comprehensive analysis of the Young Ottomans' ideas see the classic work by Şerif Mardin, The Genesis of Young Ottoman Thought: A Study in the Modernization of Turkish Political Ideas (Syracuse, NY: Syracuse University Press, 2000).

7 For details of Ali Ekrem's early life and the story of his own childhood see hid autobiographical work Ali Ekrem Bolayır, Hatıralar, edited by M. Kayahan Özgül (Hece Yayınları: Ankara, 2007). 
Vaka's, as she lived in an unquestioned ideological environment of Ottomanism because of her father's official position; it appears that she was rather unaware of the nationalist ideas at the time of the First World War. This peaceful childhood, though, was soon destroyed with the arrival of nationalist uprisings and war. Her narrative also shows that she was either uninterested in, or chose not to write about, children outside her family, either Muslim or non-Muslim.

This attitude sharply contrasts with Vaka's interest in Muslim children, and is probably due to the luxury that Ekrem enjoyed as a member of the Turkish ruling elite. Vaka's childhood in contrast, reflects an awareness and sensitivity with regard to communal difference. The narrative demonstrates that her childhood world was to a much greater extent filled with signs of national identity, or concepts like history, civilization, race, etc. Ekrem's Ottoman patriotism gradually develops during her father's posts in Jerusalem, Beirut and the Aegean Islands and evolves into a Turkish nationalism with the Balkan Wars and the First World War. As she grows, she becomes more consciously aware of her Turkish identity and the freedoms modernization offers to a Muslim girl. She is rather surprised, or even shocked, to see her childhood world crumble as non-Muslim elements of the Empire revolt against the Ottoman regime.

In what follows, I will develop Vaka's and Ekrem's stories separately, whole paying attention to parallels, similarities and divergences. I then elaborate both girls' views as regards to clothing, fashion and veiling.

\section{Vaka's Story}

\section{A Greek Childhood in Late Ottoman Istanbul}

Demetra Vaka was born in 1877 in the largest of the Prince Islands of the Marmara Sea [Büyükada], to a Greek family. Demetra's father was a bureaucrat of the Sublime Porte, so Demetra's family belonged to the cosmopolitan culture of the Ottoman capital in addition to being part of the culture of the modernizing Greek bourgeoisie. Demetra's ideas about children, women, family, marriage and her own bildung should be understood against the diverse effects of this intellectual and cultural background. While being exposed to Greek nationalist ideas from her family and from her community, she spent a lot of time with Muslim girls and boys of her own age, some of whom she befriended for a lifetime. Living in a time of political turmoil and dissolution of the Empire, her childhood was under the multiple influences of the Greek nationalism of her uncle, the Phanariot culture of a distant aunt and the late Ottoman cosmopolitanism of her father. 
However, although she reflected the mindset of the well-educated, uppermiddle classes of Istanbul's Greek bourgeoisie, her educational formation was quite exceptional among Greek women of her day. When she was eighteen, Demetra went to the USA as an unpaid governess for the children of the GreekOttoman consul to New York, and she later settled there, continuing to work as a journalist and teacher. After her marriage to an American writer, Kenneth Brown, she started a literary career in America, writing and publishing in English.

Demetra's father is at the center of her narrative; by holding a bureaucratic position, he is her link to the Muslim families and way of life. He is the one who cares about Demetra's learning Turkish, and as a politically moderate figure he was perhaps closer to Ottomanism than Greek nationalism. Demetra's mother, in contrast, does not speak Turkish and rejects socializing with Turks. Demetra's rare accounts of her mother are usually in relation to the Orthodox religious rituals that she performs, her disciplining presence and her bourgeois sensitivities. Demetra seems to be a rather lonely child, who felt closer to her father than her mother. ${ }^{8}$ About her mother, she wrote:

I believe that every time I came before her she wondered anew how I happened to be her child; for she was tall and beautiful, and very conventional in her desires, and I was small and elfish, and my desires were usually for things she could not imagine any person wanting. ${ }^{9}$

Demetra was exposed to the values of the Greek Enlightenment, through her formal and informal education. She received a classical education, studying ancient Greek and Latin, learned French and later pursued her studies in Paris, which she had to terminate upon the death of her father. Her writing frequently underlines the importance she gives to her own educational formation. Devouring books and valuing reading above everything else, Demetra is a perfect example of the authority the 'reading culture' had on the bourgeois classes in nineteenth century. Indeed, as a youngster she was very proud of her observing and dissecting mind, which she contrasted with that of the Oriental children who accepted things without much questioning. Of her Muslim friend Sitanthy she wrote: "Her mind received without stimulating her imagination. But I was a Greek child, with a mind as alert, an imagination as fertile as hers were placid and apathetic."10

8 In Bribed to be Born, Vaka potrays a positive and caring father figure as opposed to a rather distant, self-absorbed mother, preoccupied with her looks, fashion and consumption. 
Values of the Enlightenment gradually penetrated into the culture of the Greek bourgeoisie of the late Ottoman Empire through education, commercial ties and relations with the Greeks of Europe. ${ }^{11}$ Demetra also inherited ideas of Greek nationalism, through her relatives and community. In Bribed to be Born, Vaka narrates the upbringing of a little Greek girl by her great-aunt from a Phanariot background. In this novel, the little girl's aunt declares that the aim of education is "service to the Race"; that is, the Greek community. The philanthropic activities, charitable foundations and schools of the Phanariot community, as well as their daily lives around the Patriarchate, are told in detail. The Greek Phanariot community is portrayed as living a completely segregated life from the Muslims, with its own conventions, culture and social rules. Though much more conservative than the liberal Greek bourgeoisie of the time, Phanariots too, according to Vaka, had inherited values of the Enlightenment and were gradually accepting the bourgeois mentality, such as, for example, the changes in Greek women's lives brought about by economic development.

As a child, Demetra had no doubt that the Greeks were heirs to the highest civilization the world had ever known and thus they were the heart of Western civilization. However, as she grew older the mores and conventions of her own Greek community began to stifle: "I liked neither the attitude of men towards the women nor of the women towards life, among the people of my race."12 Apparently, the late nineteenth century Greek community did not offer many alternatives to young girls other than marriage and motherhood:

the usual fate of a Greek girl, who has to sit and wait until a marriage is arranged for her, seemed to me the worst thing that could befall me. And if the fate of the Greek girl with money was terrible, what could I think of a girl like me, who had no dowry? ${ }^{13}$

11 See Maria Christina Chatziioannou "Creating the Pre-Industrial Ottoman-Greek Merchant: Sources, Methods and Interpretations," in Lorans Tanatar Baruh and Vangelis Kechrotis (eds), Economy and Society on Both Sides of the Aegean (Athens: Alpha Bank, 2010), 311-336. Also Meropi Anastassiadou, "Greek-Orthodox Households in Istanbul (19th-2oth Centuries)," id., 397-422.

12 Vaka, Child, 251.

13 Ibid., 193-194. For the controversial values of the newly rising Greek bourgeoisie, see Paschalis Kitromilides, "The Enlightenment and Womanhood: Cultural Change and the Politics of Exclusion," Journal of Modern Greek Studies, 1 (1), 1983, 39-61, reprinted in id., Enlightenment, Nationalism, Orthodoxy (Aldershot: Variorum, 1994); Maria Anastasopoulou, "Feminist Awareness and Greek Women Writers at the Turn of the Century: The Case of Kalliroe Parren and Alexandra Papadopoulou," Journal of Modern 
Ultimately, she decided that her individuality, leading her life as she chose, weighed heavier than serving the Race, and she decided to go to America: "I lived in that dream of wonderful usefulness which was to be mine, and which was to save me from the martyrdom of the women of my race."14

Embracing values of Enlightenment, Demetra was critical not only of the Ottoman system in which Greeks lived, but also the limitations put on women by her own Greek community. In her view, her Greek community was superior to Turks in many ways, but still Oriental in some areas.

\section{Narrating Oriental Childhood for Western Audiences}

Vaka's career as an Orientalist writer in America demanded an emphasis on the different, exotic and uncivilized qualities of the Ottoman Orient. Vaka, however, strove hard to differentiate her literary and travel writing from Western Orientalist literature. She did not hesitate to present herself as an Ottoman woman from Istanbul to a western readership, and enjoyed the insider's position this identity provided her as a writer. ${ }^{15} \mathrm{Her}$ Istanbulite credentials, it seems, permitted her to write in a much more authoritative voice and distinguish herself from the vast literature depicting the Ottoman Orient.

When she wrote $A$ Child of the Orient, Vaka was a married woman settled in America for almost ten years. The book introduces the Orientalist stereotypes drawn from her childhood. Turks are described as an Asiatic people, associated with slavery, despotism, military aggression, polygamy, suppression of women, indulgence of the senses, etc. As the book unfolds, though, these negative traits ascribed to Turks are often counterbalanced by such positive characteristics as spontaneity, delicacy, emotionality, hospitality or practicality, which Demetra experienced in her everyday contacts with Muslim people:

In the abstract, the Turks, from the deeds they had done, had taken their place in my mind as the cruellest of races; yet in the concrete that race

Greek Studies, 15 (1), 1983, 1-28; reprinted in Philip Carebott (ed.), Greek Society in the Making, 1863-1913 (Aldershot: Variorum, 1997), 161-175.

14 Vaka, Child, 193.

15 For Demetra Vaka's complex identity see Yiorgos D. Kalogeras, "Contested, Familiar and Exotic Spaces: The Politics of Demetra Vaka Brown's Identity," introduction to Vaka Brown, Haremlik (2005 edition), v-xxv, especially viii-xii; Eleftheria Arapoglou, "Vaka Brown: The Historicized Geography/Geographic History of an Immigrant," Journal of Modern Hellenism, 21-22, 2004-2005, 83-103. Reina Lewis, Rethinking Orientalism: Women, Travel, and the Ottoman Harem (New Brunswick, NJ: Rutgers University Press, 2004), 28-31. 
was represented by the dark-eyed, pretty little Kiamele, the sweetest and brightest memory of an otherwise bleak infancy. ${ }^{16}$

Kiamele was a Muslim girl who was brought home as a companion to Demetra by her father and from whom she had learned Turkish. Apparently, quite early in her life Demetra came to realize that her devotion to Kiamele was in contradiction with how she felt about the ruling race, the Turks.

Memories of other Muslim children are crucial for Vaka's childhood narrative. It is as if through these memories that she acknowledges and appreciates her Greek childhood. In several chapters of $A$ Child of the Orient, Vaka compares her own Greek upbringing with the child rearing practices in the Turkish families she visits. Families, food, clothing and manners at the homes of her best friends Djimlah and Nashan are explained in detail. Billie Melman, in her important book Women's Orients, observed how Victorian female travelers were impressed by the visibility and presence of children and slaves in the divan, or the reception room of the harem. These British women mostly came from middle-class homes, where the visibility of children and servants was "timed and regulated." The Oriental homes, to them, were characterized by "lack of discipline" and indulgence towards children: "While the children were normally "banished from the middle-class parlour or the drawing room," in the divan, the British travellers observed, children "show up unexpectedly and are shown off." It was astonishing to see that in the harem, the children ate with adults, and they were spoken to and taken care of in public. ${ }^{17}$

In a similar manner, Vaka's observations about the harem and Oriental children reveal the newly rising middle class cultural concerns of Istanbul's Greek bourgeoisie. Her best friend Djimlah's house is the first harem Demetra enters as a little child:

There was little furniture in the house, just rugs and hard sofas, and small tables upon which were always sorbets or sweets, and cushions of all colours piled up on the rugs, where babies or grown-ups were always lying slumbering $[\ldots]$, the whole place seemed to me like a play-box, transformed into a fairy house, from which discipline, like a wicked fairy, was banished [...]. The amount they permitted me to eat was incredible [...]. Djimlah and I practically owned the house [...]. No one said "No" to

\footnotetext{
16 Vaka Child, 15-16.

17 Billie Melman, Women's Orients: English Women and the Middle East, 1718-1918: Sexuality, Religion and Work (Ann Arbor: University of Michigan Press, 1995), 157.
} 
us, whatever we did, and the old hanoum let us ruffle her beautiful clothes and disturb her even when she was asleep. ${ }^{18}$

Her accounts of these harems reflect Vaka's cultural prejudices; obviously, in these descriptions she is following the basic trends in Orientalist depictions of the Oriental harem..$^{19}$ Demetra, growing up with the values of the Enlightenment and Victorian middle class sentiments in a Greek bourgeois family, reacts to what she perceives as the Oriental childhood and upbringing, but as she matures she begins to relativize such concepts as rationality, discipline, self interest, individualism, etc. In her mind, the feeling of superiority is gradually giving way to an acknowledgement of possible flaws in her own westernized upbringing:

[...] As I grew older, the vast contrast between my race and theirs became more and more clear to me; and I had the distinct feeling of partaking of two worlds, mine and theirs [...]. In my home there were duties from my babyhood, duties which had rigidly to be performed; and things to be learned, remembered, and to be guided by. The words duty and obligation played a great role in my Greek home, and these two words, so stern, so irreconcilable with pleasure, were absent from the Turkish homes. ${ }^{20}$

She confesses that she really enjoyed the time spent with her Muslim friends and admitted that in this 'Oriental model,' too, there were things to be appreciated. In Haremlik, she writes admiringly of the simplicity and peace she finds in Oriental children:

It has always been a mystery to me that the Turks, who can produce such types of purity as we can hardly conceive of in our Western civilization, should be supposed by us to be voluptuous and sensual [...]. Often meeting a group of [ordinary Turkish children], and especially of little girls I have stopped and watched them with pleasure, because they looked so pure, so simple, above all so childlike. ${ }^{21}$

Vaka depicted the Oriental childhood that she discovered through her friends as a happier and more carefree childhood than her own:

\footnotetext{
18 Vaka, Child, 30-33.

19 Melman, Women's Orients, especially Chapters 4 and 5.

$20 \quad$ Vaka, Child, 33.

21 Vaka Brown, Haremlik, 204.
} 
I rarely invited [Djimlah] to my house. First, because my mother positively objected to Turks; and secondly because I had so little to offer her. She would have to share my life as I shared hers, and my life meant lessons, duties and discipline; so I preferred to go to her, and on Saturday nights I usually slept there. ${ }^{22}$

While associating Oriental childhood with pleasure, spontaneity and fun, though, Demetra felt that ultimately duty, discipline and hard work were more important qualities that made up an individual. "Usefulness" to one's nation and to society was a key concept for the young Demetra. It is as if she perceived life in clearly segregated spheres of enjoyment and work:

I came to them ready to enjoy them [...] and yet as years went by, deep down in my heart I felt glad to be a Greek child, even though I belonged to the conquered race; and I began to return to my home with greater satisfaction than I had at first, and to put into my studies a fervour and willingness which might have been less, had I not been a visitor to these Turkish households. ${ }^{23}$

A sense of superiority vis-à-vis Oriental children and a rather early awareness of the existence of different models of childhood, indicate that Demetra, as a member of a non-Muslim community, was more conscious of ethnic, religious and cultural differences than Ekrem, who was a member of the Muslim ruling elite.

In religious matters, as in other issues, Demetra defended her own position strongly among her Muslim friends. One day, playing with Djimlah, there is a disagreement over the meanings of 'God' and 'Allah.' Demetra is quite sure that the Christian 'God' is different from the Muslims' 'Allah,' while Djimlah asserts that " there is but one God, that is 'Allah' and we are His children." ${ }^{24}$ Finally, it is Djimlah's grandmother who consoles the two girls and resolves the problem:

Well, my sweet yavroum, you are all mixed up about just where you stand before God. At present you stand nowhere, because you are only babies.

\footnotetext{
22 Vaka, Child, 6o-61.

23 Ibid., 35 .

24 Ibid., $49-50$.
} 
As you grow older your place will be determined by your usefulness in the world, your kindness and gentleness $[\ldots] .{ }^{25}$

Demetra is then consoled, and contemplating on this particular event she writes:

Just as my idea of the ferocity of the Turks in their homes had long ago vanished, so what they believed and taught God to be appealed to me; and although I retained my own idea of the relative importance of the two races in this world, I could not help feeling that perhaps the old hanoum was right and that our positions before God was less a matter of creed and belief than of how we lived our lives. ${ }^{26}$

Orientalist literature representing Oriental people as primitive, uncivilized and childlike is a characteristic that has been often noted. ${ }^{27}$ For Demetra, not only were Muslim children more childlike than Greek children, but Turkish women were also childlike in their spontaneity and simplicity. They laughed like children and disclosed their feelings, happiness, fun and sorrow unreservedly:

[...] as I grew older, I liked the Turks more and more, though in my liking there was a certain amount of protective feeling, such as one might feel for wayward children, rather than for equals. ${ }^{28}$

Obviously, the childhood metaphor was extended to women and served Vaka's literary interests.

In sum, Muslim childhood was both a counter-model against which Vaka could measure the superiority of her own Western upbringing, and a vintage point from which she could evaluate Western modernity. In other words, to the extent that she found in Muslim children qualities serving as an antidote against the harshness of modern life, her nationalist/Orientalist bias with respect to Muslim childhood faded away. Conceived as a site of

\footnotetext{
25 Ibid., 59 .

26 Ibid.

27 Ashis Nandy, The Intimate Enemy: Loss and Recovery of Self Under Colonialism (Delhi: Oxford University Press, 1983), especially Chapter 1 (1-63).

28 Ibid., 35 .
} 
purity, innocence and spontaneity, Muslim childhood seems to have served Vaka's romantic criticism of modernity. ${ }^{29}$

\section{Ekrem's Story}

\section{A Turkish Childhood Encountering Modernity}

Ekrem's childhood narrative attests that there were multiple child rearing patterns among Istanbul's Muslims in the late Ottoman Empire. The division, it seems, was not necessarily along class lines, since many upper-class families as well as the palace could retain traditional (Oriental) childhood model, whereas more modest families with newly rising bourgeois, military or bureaucratic backgrounds were receptive to modern child rearing practices; ${ }^{30}$ rather, the major dividing line was between Westernized and non-Westernized families. Obviously, the childhood narrated by Ekrem does not fit the Oriental model of childhood depicted by Vaka. In fact, one has a sense that Ekrem's memories attempt to correct the Orientalist biases about Turks, and to show Western readers how at least some Turkish families were accommodating to a modern life style. ${ }^{31}$

Selma Ekrem was born in 1902, in Istanbul. As noted above, her grandfather was the famous liberal Ottoman writer Namik Kemal, and her father, Ali Ekrem, was a literary figure in modern Ottoman literature group, the Servet-i Fünun. He was also a professor of literature in Galatasaray Sultanisi [High School) and Istanbul Darülfünün [University], employed as a secretary in the Hamidian regime and later served as governor in Jerusalem, in Beirut and the Aegean Islands of Rhodes and Mytilene. Her mother was Zeynep Celile Hanim, daughter of Djelal Pasha, the French-educated son of a wealthy family who was an aide-de-camp of Sultan Aziz and a general in Sultan Hamid's army. Selma

29 Judith Plotz, Romanticism and the Vocation of Childhood (New York: Palgrave, 2001), especially Chapter 1 (1-40).

30 For various developments in late Ottoman children's lives see Cüneyd Okay, Osmanlı Çocuk Hayatında Yenileşmeler, 1850-19oo (İstanbul: Kırkambar Yayınları, 1998); id. Eski Harfli Çocuk Dergileri (İstanbul: Kitabevi, 1999).

31 While trying to stand against Orientalist bias, Ekrem employed an Orientalist discourse herself when depicting the Arabs she met in Jerusalem, in the desert or in Beirut. Both Carolyn Goffman and Özlem Ezer have noticed that Ekrem was writing as an "Ottoman Orientalist" herself when portraying the Muslims of the Eastern provinces as filthy, savage, amd underdeveloped. Carolyn Goffman, "Introduction," in Selma Ekrem, Unveiled (2005 edition), xiv-xv; Özlem Ezer, Üç Kadın Seyyahımızın Kaleminden Doğu, Batıve Kadın, 1913-1930 (İstanbul: Kitap Yayınevi, 2012), 104-116. 
experienced the political turmoil and unstable environment of late Ottoman society very closely, due to her father's uneasy relationship with Sultan Hamid and his subsequent assignment to posts away from the capital. Her childhood was marked with these official missions in the provinces, frequently packing and moving house. As a child she was mostly educated at home by older relatives and a French governess. She briefly studied the Koran with a hodja and Turkish with a male teacher. ${ }^{32}$ Ekrem later went to the American College for Girls in Istanbul. Around 1923 she went to the USA, in search of a new life of freedom. She made a living there giving lectures about Turkey to American audiences and writing regularly for newspapers and journals such as the Christian Science Monitor. ${ }^{33}$

In Ekrem's family, with its bureaucratic and literary credentials, education was considered very important for both boys and girls. Thus Ekrem was raised in an environment of freedom and domestic equality with boys, while facing the pressures that late Ottoman society placed on girls and women. In her extended family, there were both Westernized and quite traditional figures who were equally respected and loved by Selma. In the outside world, on the other hand, a growing-up Selma faced public harassment from both male and female crowds for not wearing the loose black gown called charshaf. The issue becomes an existential matter for Selma and she takes a vow not to wear the charshaf or veil. Selma's childhood ends with the charshaf crisis and the ensuing realization of the merits of modernity.

Her family's Ottoman bureaucratic background, her Turkish patriotism, her admiration of Anglo-Saxon culture and American women, gave her mixed feelings of loyalty. Ultimately, after travelling and living in the usa like Vaka, Ekrem paid homage to the family values, parent-child bonds and manners she had grown up with in late Ottoman society. As for Vaka, Ekrem's admiration of things American went hand-in hand with a critique of certain aspects of modern life that she encountered in the UsA.

Like Demetra's father, Selma's father is at the center of her childhood narrative and seems to be a source of confidence and security in an otherwise unsafe environment: it is on her father's facial expression, mood and comportment that Selma's and the whole family's mood depends. The family seems to have adopted the European middle-class ethos where respectability, etiquette and education are valued. Yet Selma's family diverges from the Victorian middle class ideals remarkably in other areas, and Selma's extended family of aunts,

\footnotetext{
$32 \quad$ Ekrem, Unveiled

33 Goffman notes that she wrote for the Christian Science Monitor regularly from late 1950s to 1972; Goffman, "Introduction," v.
} 
uncles, cousins and her grandfather is a combination of the Eastern and Western middle-class models. While males are at the top of the family hierarchy, women have an undisputed authority in domestic affairs and the running of the house. Selma's mother is the homemaker, and also a rather Westernized figure, a sensitive but persistent woman; Ekrem often recounts her mother smoking in her nervousness or anxiety. For Selma as a child, her mother is a source of authority for her and the servants, and of organization and soft discipline. Ekrem's narrative indicates that she received care and softness more from her nurses than from her constantly busy and worried mother. Selma's education is never as intense and value-laden as that received by Demetra; her training as a child is rather unsystematic and sporadic, although the family is keen on the education of the children, with her older brother and sister sent to French convent schools after their home education. Overall, in Ekrem's narrative the topic of education does not receive the same attention as it does in Vaka's. In Vaka's narrative, children's education is vital not only for the nation's progress but also for personal interest and development.

Home is at the center of Selma's childhood. Home represents coziness and safety and an escape from the turbulences of the outside world, and it is also a site of leisure, play and joy as well as obedience. From Selma's narrative it is clear that respect for adults and the elderly was of critical importance; yet children could spend time with the adults, eating and playing with them. Especially, her grandfather's big house up the hill in Arnavutköy is a refuge to where the family always returned from her father's missions in the provinces, and where Selma seems to have passed her happiest days. In this dreamlike episode of her life, Selma enjoyed a beautiful garden, numerous rooms, servants and a big family; with her older brother and sister as well as her little sister and cousins, Selma appears always to have had company around her, and her autobiography does not mention other children. ${ }^{34}$

Her great grand-mother's house in Yildiz is another dearest place. The house represents old-time manners and culture untainted by modernity:

[...] the instant I was in it I knew I had come to a world different from my own. A world that was like an old Turkish embroidery hiding away in a deep trunk that dazzles one with its bright play of colors when it is brought to the light so that one looks at it long with love and admiration. ${ }^{35}$

\footnotetext{
34 It should be noted that Selma did not include in her memoirs the tragic suicide of her brother Cezmi due to an unrequited love in 1917 or the loss of her older sister in Cairo due to typhoid fever. Ali Ekrem, Hatıralar, 165 n., $221 \mathrm{n}$.
} 
The house is described in terms of "a crack in the door," "a dark but not gloomy hall," "straw-matting," "snow-white rooms," "a low white divan," "soft mattresses on the floor," and "a faint fragrance of lavender," all associated with cleanliness, comfort and serenity. ${ }^{36}$ Ekrem confesses her feelings about her great grandmother:

She looked at us from her world that now lies in heaped-up memories, a world that is never to come back, the fragrance of which lingers only among a few chosen people. Great-grandmother was to me the old Turkey that was more enchanting than any fairy tale. ${ }^{37}$

The great grandmother represents the past bairams [holidays], philanthropy, visitors and old retainers and slaves, a house where "ladies and kalfas ate together."38

In spite of all the respect and reverence felt for her great grandmother, Selma acknowledged that she belonged to a bygone era:

She whom I loved and admired was a different person from a world different from the world I knew. With all her greatness and her wit, she too had bowed to all restrictions and had worn and was still wearing her black tcharshaf. The old days were beautiful, my grandmother I loved, but I could not be like her. ${ }^{39}$

Upon arrival in America, Selma met young American girls around her own age. Her observations of these girls allowed Selma to contemplate her own girlhood in Istanbul. When a group of girls came to visit them at her friend's house in Washington, DC, she felt a stranger: "Some of these American girls were of my own age and some even younger, but before them I felt myself a child."40

The girls' talk about dates, boyfriends, make-up astonished Selma, who never mentioned boys, sexuality and romantic relations in her memoirs:

The talk centered round the person whom the girl who had closed the phone referred to as the "boyfriend." I came to learn that this distinctly American commodity existed in the life of almost every girl. Some of the

\begin{tabular}{ll}
\hline 36 & Ibid., 185-187. \\
37 & Ibid., 186. \\
38 & Ibid., 188-189. \\
39 & Ibid., 190. \\
40 & Ibid., 309.
\end{tabular}


girls had a number of them and some changed them at will [...]. He was not the dutiful aloof fiancé of pre-war European type, chosen by parents and accepted by dutiful daughters. ${ }^{41}$

Interestingly, Selma, who admired the political and social freedom of these girls, questioned them when it came to relations with the opposite sex. She even thought American girls matured too early and acted like grown-up women in matters concerned with the opposite sex:

I could not find children in America. Even little schoolgirls were grown up, went to dances, and rouged their faces. Could these girls listen entranced to the tales of djinns and peris which my old nurse had told so lovingly and which I had listened to for so many years [...]? Fairies and fairy tales were out of style here in this era of jazz and Charlestoning. I never could sail my kite in this wind [...]. The freedom I wanted would have to be tempered with some submission to the days that were no more. $^{42}$

Selma had just escaped the circumstances which were pushing her into an early womanhood in Istanbul, and her protected world of girlhood would not yet incorporate anything reminding her of womanhood. In the American girls, she had sensed an eagerness to become a woman and she found this disturbing. Sticking to a rather desexualized girlhood, she rejected dates, boyfriends and make-up. For her, girlhood was not a preparation for womanhood but more an extended stage of childhood and she was determined to keep it like that.

\section{Ekrem's Politics: From Ottomanism to Nationalism}

The atmosphere in Selma's home was always charged with politics wherever they went. While political issues were not discussed with children, Selma tried to pick up pieces of information by asking her nurse and servants. Her father's posts ensured that ethnic struggle among the different religious communities, Arab nationalist revolt and Greek nationalism made deep impressions on Selma's otherwise peaceful childhood world. These missions in the distant provinces of the crumbling Empire were associated with feelings of fear, anxiety and a deep distrust passed on to Selma from her mother's and father's facial

\footnotetext{
41 Ibid., 310.

42 Ibid., 313 .
} 
expressions, from the whispers of adults, from the stressful atmosphere at home.

The financial security of Selma's upper-class, well-to-do childhood household seriously declined with the loss of her father's occupation as a governor of Mytilene after the capture of the island by Greece in the Balkan War. Apparently, Selma did not question the meaning of ethnic revolt in her own Ottoman childhood existence. It is only after the declaration of the Balkan War, witnessing the rejoicing of the Greek passengers on the ship to Mytilene did Selma feel anger:

For the first time I had felt a dislike for a group of people that I did not even know. Their rejoicing had cut me [...]. Turkey was one big graveyard $[\ldots]$. And to think that these people on the boat were gay, as they went to join the armies that would fight my country. ${ }^{43}$

During Greek army's subsequent occupation of the island of Mytilene, she started painfully to realize that her fragile childhood world as a member of the Ottoman ruling class was shattering for good. During the whole family's captivity in Piraeus, she says she physically met "the enemy." Her family's living standards further declined after the First World War and the occupation of Istanbul by the Allied armies; the occupation also brought a further realization that her old Istanbul was gone.

In this heavy atmosphere, the American College for Girls was like a safe haven where Selma could stay away from politics and war and become a child again:

I loved the school now, in its four walls I put everything else out of my mind. There the horror of war and death had to be forgotten with books. There I did not hear the rustle of newspapers, the moans of poverty, the talk of food and clothing, and the criticisms that my hat roused. [...A ]nd only then did I become a child." ${ }^{44}$

But when the Allied occupation of Istanbul was met with joy and celebration among the non-Muslim girls of the college, Selma clearly felt her nationalist feelings being aroused. Celebrating crowds on the streets deepened her pain and anger:

43 Ibid., 215-216.

44 Ibid., 270. 
At college mournful groups of Turkish girls pored over the newspapers $[\ldots]$. The occupation of Symrna by the Greeks had revolted us [...]. Turkey would cease to exist-a greater disaster than the Great War had fallen upon us $[\ldots]$. We could not bear to look at the other girls, those who were not Turks and who lived their happiest days in our blackest ones. ${ }^{45}$

On her return to Turkey from the USA in 1923, Selma realized that she had arrived in a new Turkey, the new Republic:

The child of old Stamboul would live as a dim memory in my mind, for old Stamboul was dead and buried under the centuries [...]. But no matter how happy I was in Turkey, the far-off call of America would never leave me." ${ }^{.46}$

No matter how much she appreciated the changes the Republic brought, she would return to America longing for the action, restlessness and tonic it offered. Her later writings attest that Selma's nationalism remained as a short-lived defensive response to ethnic uprisings and war, and did not determine her adult identity. As a writer, she preferred to write nostalgic pieces about old Istanbul. ${ }^{47}$

\section{Clothing for Girls}

Clothing was an important issue for both Demetra and Selma, since theirs was a time when traditional clothes were slowly being replaced by Western children's clothes. ${ }^{48}$

In Istanbul's Greek community western clothes had already become a sign of status and prestige, while among the upper class Muslims, too, Western fashions were gradually being adopted. Memories, photographs and advertisements reveal that children's clothing followed the Western fashion as well. A favorite costume was sailor's clothes for both boys and girls. White linen clothes and hats for children were indispensable for upper-class and Westernized Greek children. ${ }^{49}$ Vaka recalls: "I never wore anything myself

\footnotetext{
45 Ibid., 280.

46 Ibid., 319 .

47 Goffman, "Introduction," vi.

48 Cüneyd Okay, Osmanlı Çocuk Hayatında, 79-83.

49 Yorgo L. Zarifi, Hatıralarım, Kaybolan Bir Dünya; İstanbul 1800-1920, translated by Karin Skotiniyadis (İstanbul: Literatür, 2005).
} 
except simple white linen, with an English sailor hat, my sole adornment the name of her majesty's dreadnought on its ribbon."${ }^{50}$ She found the traditional Muslim women's and little girls' clothing too exaggerated and tasteless, as her story of Nashan indicates.

Demetra got to know her friend Nashan during a walk she was taking with her father. The little girl Nashan was on a donkey dressed up in fancy and exaggerated clothes:

I knew her by sight, as children know each other, and she always aroused the liveliest interest in me on account of her costumes [...]. Today she had a velvet gown, trimmed with gold lace, and made in the latest Parisian fashion for grown-up women. Her silk mittened hands [were] bejewelled with rings and bracelets [...]. On her head perched a pink silk hat $[\ldots]{ }^{51}$

When the two groups saluted each other, Nashan remarked: "Father, this is the little girl I was telling you of - the one that always dresses in sheeting."' And Demetra replied: “'And you are dressed like a saltimbanque!," Nashan in turn replied: "Oh, it's not true [...]. I am dressed like a great lady." 52 The next day Demetra and her mother were invited to Nashan's home, the konak of a powerful pasha. Demetra's mother, who had never crossed the threshold of a Turkish harem before, was forced to accept the invitation. To their surprise the pasha's wife, who had come from Anatolia, asked for her advice on Nashan's clothes:

In very polite words my mother conveyed to her that European women did not wear gaudy clothes in the streets $[. .$.$] and the woman from the$ remote district of Anatolia comprehended that her child was not dressed as a well-dressed European child would be..$^{53}$

From that day on, Nashan also started to dress in "sheeting" and began to be educated in a European manner. It is ironic that years later Vaka deplored that Nashan had grown alienated from her native culture: "Usually, I am sorry to say, she more and more lost her native simplicity, with her acquirement of European culture, and more openly despised the customs of her own country." 54

\begin{tabular}{ll}
\hline 50 & Vaka, Child, 74. \\
51 & Ibid., 73-74. \\
52 & Ibid., 75. \\
53 & Ibid., 82. \\
54 & Ibid., 83.
\end{tabular}


Photos from Ekrem's book also show that the women of her family were dressed in Victorian-style dresses and hairstyles at home and in the garden, while wearing the charshaf in public. Linen dresses and sailor's clothes again seem to be the typical attire for children. Selma wrote that her mother always made them wear blue sailor suits and a blue woollen sailor cap with two black ribbons hanging down her back: "I loved my sailor suit for it had such deep friendly pockets and I was proud of my cap. Mother always made us wear these suits, which she bought at an English store." ${ }^{\prime 55}$ In informal family photos the girls do not wear hats, while men and boys wear the fez, yet out on the street the Ekrem family's girls wore western hats and continued wearing them until they were met with repeated negative public reactions.

Often, passing by a coffee house, they would be harassed by old men:

One old man rose to his full height and shook the slender neck of his nargile at us: "It is a sin, hanoum, a sin" he shouted. "Your children are wearing hats as the Christians do. Are you not a Moslem?"

The voice of the man filled the street and the other people turned to us in wrath [...]. Then a crowd of old women, faces hidden in thick veils, were round us gesticulating and heaping maledictions on our heads. ${ }^{56}$

Selma was the only girl in the family who did not give in to street mobs' pressures. As a young girl, wearing the hat was such a vital issue for her since she did not want to put on the charshaf:

One escaped sultans and cyclones but not the tcharshaf. Millions of women had worn it before me. And to my eyes came these women, in thick clusters, wrapped in blackness, their faces covered [...]. I would fight, I would tear these shadows from me, the million bundles could sneer at me and revile me, but I would not be a bundle. I wanted to feel the wind and the air on my face forever $[\ldots] .{ }^{57}$

While her older sister and mother did not mind wearing the charshaf in public places, Selma simply rejected wearing it. Interestingly, despite all the public pressure and finally police orders to put on the charshaf, her family did not make Selma wear it; instead, they sought for alternative solutions. Selma's mother agreed, saying: "They are too young for the tcharshaf and I cannot

\footnotetext{
$55 \quad$ Ekrem, Unveiled, 46.

56 Ibid., 194-195.

57 Ibid., 180.
} 
make them wear the bash-urti, that white rag which others tie over their children's heads." 58 Thus Selma was first made to wear the Arab girls' headgear kufie, then a bonnet with big ribbons and finally, when these also drew considerable public protest, she had her hair cut like a boy. "With that hair and a hat I could not be Turkish. Surely I must be an eccentric American left in Stamboul by mistake. And thus with pretense and fear I wore my hat."59 Selma's revolt, it seems, was so strong that she was ready to leave behind her Turkish identity and crossdress as a boy.

Vaka, who consistent with the Orientalist genre always admired Oriental clothing, described Oriental women's' clothing at length in her books. According to her, Istanbul's women looked best in their traditional clothes and when they did not imitate western clothing. She was very happy, for example, to see her friend Nashan to proudly put on the richly embroidered Anatolian garments sent by her fiancé's mother. ${ }^{60}$ Vaka did not express any distaste for the charshaf and veil worn by Muslim women. While noting "the initiation to charshaf" of her Muslim friends, Vaka actually used a matter-of-fact-tone in total contrast to Ekrem:

That year was a memorable one in our lives, because it was the last in which my three playmates would be permitted to go uncovered, and play with children of both sexes. They were now nearing the age at which little Turkish girls become women, must don the tchir-chaff and yashmak [.... Djimlah's grandmother] decided that it would be very good for the three Turkish girls to go twice a week and spend the morning at Nizam, where all the European children congregated. She wanted Djimlah to see as much of the European world as possible before she was secluded. ${ }^{61}$

Vaka also observed that some Muslim families were already permitting their girls to go around with uncovered hair:

[Semmeya] was much older than any of us, and she ought to have been wearing the tchirchaff, and to have been living in the seclusion of the haremlik, but her people were not very orthodox, and Semmeya had a way of her own of getting what she wanted [...]."62

\begin{tabular}{ll}
\hline 58 & Ibid., 196. \\
59 & Ibid., 269. \\
60 & Vaka, Child, 215. \\
61 & Ekrem, Unveiled, 111-112. \\
62 & Ibid., 113.
\end{tabular}


Clothing seems to have become a sign of modernization, civilization and cultural identity in this period of change in the Ottoman Empire more than ever. Clothing was a much more sensitive issue for Selma than it was for Demetra. For Demetra, her westernized clothing was a sign of civilization and progress, underlining her difference from Muslim children. Yet overseas in America, as an author describing Oriental women, she expressed her admiration of Oriental clothing.

For Selma, how she was going to be dressed was an existential matter and she was aware all the time of the implications of her clothing. She knew well that wearing the charshaf would be seen a sign of her initiation into Muslim womanhood, an identity she refused to take up.

\section{Conclusion}

Both girls grew up in modern and privileged families of Istanbul. Due to their fathers' professions, both were exposed to the political currents and instability in late Ottoman Istanbul. Both girls took Enlightenment values so seriously that they left their homes to start life anew in America. Appreciating the freedoms gained by American women and enchanted by the pace of modern life in America, they nevertheless longed for the protection that Ottoman society had offered, now lost.

Vaka's early encounter with Greek nationalism gave her a greater political awareness than Selma. Her childhood recollections reflect a rather serious, disciplined and inquisitive character. Ekrem's political consciousness and national identity develop at an older age, and this is why her childhood memories have a more dreamy and impressionistic quality. While Vaka's writing portrays a determined child who is resolved to free herself from social and political bondage, Ekrem's childhood self simply watches and is carried away by events. The turning point for Ekrem is the veiling issue, where she asserts herself as a young girl for the first time.

Both Vaka's and Ekrem's memories ultimately challenge the Orientalist discourse on late Ottoman life. Assured that her own upbringing and education are superior, Vaka writes in the Orientalist style when describing her Muslim friends. However, I have argued here that Vaka's writings on Oriental childhood waver between a modern, bourgeois moralist stance praising rationality, order, discipline and work as values essential for her own cultivation, and a simultaneous fondness of the childlike, indulging, sensual and disorderly features that she finds in Muslim children. Ekrem's memories, on the other hand, were written as a response to Orientalist depictions of Ottoman Muslims' lives. Challenging the 
clichés about an Orient frozen in time, the story of her childhood emphasizes change, disruption and the tension introduced by the arrival of modernity.

Selma's childhood, like Demetra's, was a modernizing childhood, but with peculiarities. Her childhood in a Muslim family witnessed deeper tensions with regard to westernization than that of Demetra's Greek childhood, where she could more easily revolt against the Oriental ruling culture and adopt Westernization. Perhaps the most important tension Selma experienced was her refusal to wear the charshaf and the veil as a sign of moving from childhood to womanhood. In doing that, she wanted to protect herself from an abrupt move into womanhood, and spend more time in girlhood.

For both girls, leaving childhood and moving ahead into womanhood was a challenge. Instead, girlhood offered a safer realm, where they could exercise freedom, mobility and individuality. By settling and working in America, they could prolong their girlhood. Opting for girlhood was their feminist response to religious and communal pressures.

\section{Bibliography}

\section{Primary}

Ekrem Bolayır, Ali, Hatıralar, edited by M. Kayahan Özgül, Hece Yayınları: Ankara, 2007.

Ekrem, Selma, Unveiled:Autobiography of a Turkish Girl, New York: Ives Wahburn, 1930;

Piscataway, NJ: Gorgias Press, 2005.

Ekrem, Selma, Turkey, Old and New, New York: C. Scribner's Sons, 1947.

Ekrem, Selma, Turkish Fairy Tales, Princeton, NJ: Van Nostrand, 1964.

Vaka Brown, Demetra, Haremlik: Some Pages from the Life of Turkish Women, New York:

Houghton Mifflin, 1909; Piscataway, NJ: Gorgias Press, 2005.

Vaka, Demetra, A Child of the Orient, London: John Lane, The Bodley Head, 1914.

Vaka, Demetra (Mrs Kenneth Brown), Bribed to be Born. New York: Exposition Press, 1951.

\section{Secondary}

Akşit, Elif Ekin Kızların Sessizliği, Kız Enstitülerin Uzun Tarihi. İstanbul: İletişim, 2005. Anastasopoulou, Maria, "Feminist Awareness and Greek Women Writers at the Turn of the Century: The Case of Kalliroe Parren and Alexandra Papadopoulou," Journal of Modern Greek Studies, 15 (1), 1983, 1-28; reprinted in Philip Carebott (ed.), Greek Society in the Making, 1863-1913, Aldershot: Variorum, 1997, 161-175.

Anastassiadou, Meropi, "Greek-Orthodox Households in Istanbul (19th-2oth Centuries)," in Lorans Tanatar Baruh and Vangelis Kechrotis (eds), Economy and Society on Both Sides of the Aegean, Athens: Alpha Bank, 2010, 397-422. 
Arapoglou, Eleftheria, "Vaka Brown: The Historicized Geography/Geographic History of an Immigrant," Journal of Modern Hellenism, 21-22, 2004-2005, 83-103.

Chatziioannou, Maria Christina, "Creating the Pre-Industrial Ottoman-Greek Merchant: Sources, Methods and Interpretations," in Lorans Tanatar Baruh and Vangelis Kechrotis (eds), Economy and Society on Both Sides of the Aegean, Athens: Alpha Bank, 2010, 311-336.

Ezer, Özlem, Üç Kadın Seyyahımızın Kaleminden Doğu, Batıve Kadın, 1913-193o, İstanbul: Kitap Yayinevi, 2012, 104-116.

Goffman, Carolyn "Introduction," in Selma Ekrem, Unveiled, Piscataway, NJ: Gorgias Press, 2005, v-xxxxi.

Kalogeras, Yiorgos D., "Contested, Familiar and Exotic Spaces: The Politics of Demetra Vaka Brown's Identity," introduction to Vaka Brown, Haremlik (2005 edition), v-xxv.

Kitromilides, Paschalis, "The Enlightenment and Womanhood: Cultural Change and the Politics of Exclusion," Journal of Modern Greek Studies, 1 (1), 1983, 39-61, reprinted in id., Enlightenment, Nationalism, Orthodoxy, Aldershot: Variorum, 1994.

Lewis, Reina, Rethinking Orientalism: Women, Travel, and the Ottoman Harem, New Brunswick, NJ: Rutgers University Press, 2004, 28-31.

Mardin, Syerif, The Genesis of Young Ottoman Thought: A Study in the Modernization of Turkish Political Ideas, Syracuse, NY: Syracuse University Press, 2000.

Melman, Billie, Women's Orients: English Women and the Middle East, 1718-1918: Sexuality, Religion and Work, Ann Arbor: University of Michigan Press, 1995.

Nandy, Ashis, The Intimate Enemy: Loss and Recovery of Self Under Colonialism, Delhi: Oxford University Press, 1983 .

Okay, Cüneyd, Osmanlı Çocuk Hayatında Yenileşmeler, 1850-19oo, İstanbul: Kırkambar Yayınları, 1998.

Okay, Cüneyd, Eski Harfli Çocuk Dergileri, İstanbul: Kitabevi, 1999.

Plotz, Judith, Romanticism and the Vocation of Childhood, New York: Palgrave, 2001.

Zarifi, Yorgo, L., Hatıralarım, Kaybolan Bir Dünya; İstanbul 180o-1920, translated by Karin Skotiniyadis, İstanbul: Literatür, 2005. 